\title{
Comparative Analysis Regarding Managerial Flexibility within Romanian Public and Private High Schools
}

\author{
Catalina TEACU SPAC ${ }^{\star}$, Mioara JICMAN ENACHE ${ }^{\star \star}$
}

\begin{tabular}{l}
\hline \multicolumn{1}{c}{ A R T I C L E I N F O } \\
\hline Article history: \\
Accepted August 2020 \\
Available online August 2020 \\
\hline JEL Classification \\
D12, M31 \\
Keywords: \\
Educational management, \\
Educational leadership, \\
Performance, Flexibility, \\
Educational development plan
\end{tabular}

\begin{abstract}
A B S T R A C T
While recent research has shown that management staff plays a crucial role in the process of increasing educational institutions, we know very little about their role in shaping decision-making effects on institutional performances. We address this issue by comparing the impact of management from both public and private high schools in Romania on their performances. We hypothesize that the management flexibility in private high schools matter more in terms of performances than the hierarchical structures from the public funded high schools. Based on parallel surveys of public and private high schools, we confirm that performance is perceived differently in these institutions. We therefore suggest that public management should pay more attention to their role in supporting performance.
\end{abstract}

(C) 2020 EAI. All rights reserved.

\section{Theoretical background}

Educational management is at a turning point by embracing a new era of global innovation, transformation and growth, in which management staff must discover new ways of doing things in order to identify concrete ways to achieve a higher degree of efficiency. Educational management must focus on the critical points for development, entrepreneurship, innovation, institutional cooperation as well as development through free exchange and globalization (Bush, 2008).

In an ideal educational system, the aim is to eliminate any administrative bureaucratic issues and develop structures specific to democracy, such as organizational and decision-making decentralization (Walberg et al., 2000). The purpose of these actions would be in particular to eliminate excessive centralism and support organisational flexibility, in order to ensure the possibility of taking decisions. The goal is also to stimulate the creative and participatory initiative of teaching staff in finding and applying valuable and efficient management solutions, in optimizing the management of both the collective bodies and the members of the educational communities (Bolam et al., 2005; Huffman, 2011).

The manager, as the head of the educational institution, plays an important role in the management of the educational units. If successful, the manager should be relieved of the pressures of over-centralization and administrative bureaucracy and should be concerned with setting flexibility-based strategies for the institutional development (McTavish, 2006). For the educational manager to be able to lead to a desired level of performance and efficiency, it is necessary to have professional competence and experience in the field, accompanied by the ability to initiate, to properly address the problems, the ability to use his own strengths and to take any risks. For the success of the management act, the school manager must prove exigency, but also imposing correct behaviour, civilized in all situations, as well as: flexibility, innovative and creative spirit, increased professional, legal and managerial responsibility (Darling-Hammond et al., 2019).

Considering that any managerial activity also includes a psycho-socio-pedagogical dimension (human relations, information, explanations, guidance, applications, etc.), the educational manager is required to have a specific psycho-pedagogical training in addition to a specific managerial training (Tudor, 2015). Educational managers must act on the basis of specific procedures, which will affect their relationships with colleagues and provide them with the necessary protection, both as legal bodies and as individuals and this in accordance with the constitutional provision (Mulford, 2003). The efficiency of the educational managerial activity is achieved using appropriate methodological procedures, such as: meetings, negotiation, conciliation, mediation, delegation, teaching staff consultancy, and others as well (Bunaiasu, 2014).

Educational institutions must prove the existence of both performance assessment dimensions, namely efficiency (accomplishment of strategic goals) and efficacity (accomplishment of activities) to be good

\footnotetext{
${ }^{\star},{ }^{\star \star}$ Dunarea de Jos University of Galati, Romania. E-mail addresses: catalina.teacu@ugal.ro (C. Teacu Spac - Corresponding author), mioara.jicman@ugal.ro (M. Jicman Enache)
} 
performers. In practice, educational managers need to balance the need for efficiency with the need for efficacity (Leithwood and Jantzi, 2008).

An effective educational manager should have methodological competences: learning skills, creativity, flexibility, working method, initiative, independence, strategic thinking skills (analytical, synthetic); professional competences: professional knowledge and skills, quality of work, working techniques, working time; social competences: awareness of responsibility, the ability to criticize, to work in a team or to establish relationships, the ability to express oneself (Black, 2015).

Regarding the managerial function of design / planning, the indicators of competence involve: establishing the strategy of the training process coordination (setting the objectives of the training process; establishing the methods and procedures for achieving the objectives; establishing the monitoring and evaluation methods of the training process) and planning the training process (analysing the human resources involved; evaluating the existing technical-material and documentation base; planning the training process - providing curricular documents, updated and approved) (Wentland, 2003).

In what concerns the flexibility role in organizational management function, the competence indicators involve the assurance of human, financial, material, informational and time resources in order to reach the goals established by the educational projects (identifying the concrete activities necessary to reach the objectives; establishing and assigning the necessary human resources; identifying the sources of financing; and procurement; argued support for funding requests) and establishing communication, decision and reporting lines (setting responsibilities; setting reporting deadlines; reporting structure requirements) (Ng et al., 2006).

For the managerial function of operational management, the competence indicators involve ensuring the quality of the training process (approving / approving the training activities; verifying the activity of the personnel with attributions in the field and making decisions to solve the disfunctions; monitoring the activities within the planned deadlines), ensuring a climate optimal for conducting the training process (preparation of sessions; encouraging participation in discussions; identifying causes of dysfunctionalities in conducting training; making decisions / proposing measures for the operational solution of the malfunctions) and coordinating the training process (providing specialized consultancy; presenting the report; operational information on the status and quality of the tasks performed) (Rosenblatt, 2001).

Regarding the managerial function of optimization, the competence indicators involve ensuring the professional development of the personnel (evaluating the personnel training activity in relation to the proven quality of the professional act; establishing the training needs according to the professional development requirements of the personnel and with the needs of the organization) and perfecting their own activity (studying the offers of improvement in the field of educational management; establishing the best form of improvement of the training; active participation in different forms of improvement, adapted to the specific activity of the training and training of the personnel) (Allan, 2007).

\section{Method}

The study is based on descriptive statistics. The data has been collected with an online questionnaire (https://forms.gle/SjoZnu8PV4PeLN9H8) from 200 teachers involved in Romanian public funded high schools (100), respectively privately funded high schools (100). The answers were gathered in January 2020 and validated in a SPSS database. The questionnaire involves twenty items based on five points Likert scale aiming at identifying teachers' perception about managerial staff from their institutions regarding their actions toward performance increase, as well as one item representing the independent variable in the research conceptual model : public and private high schools.

The conceptual model (Figure 1) brings together the educational institution type (public or private) on one side, and three dependent variables (the flexibility of the institutional development plan and its adaptability to the realities of the socio-economic environment; teachers' involvement in the implementation of the school development plan; the impact of flexibility of the management team on the performance of the institution) on the other side.

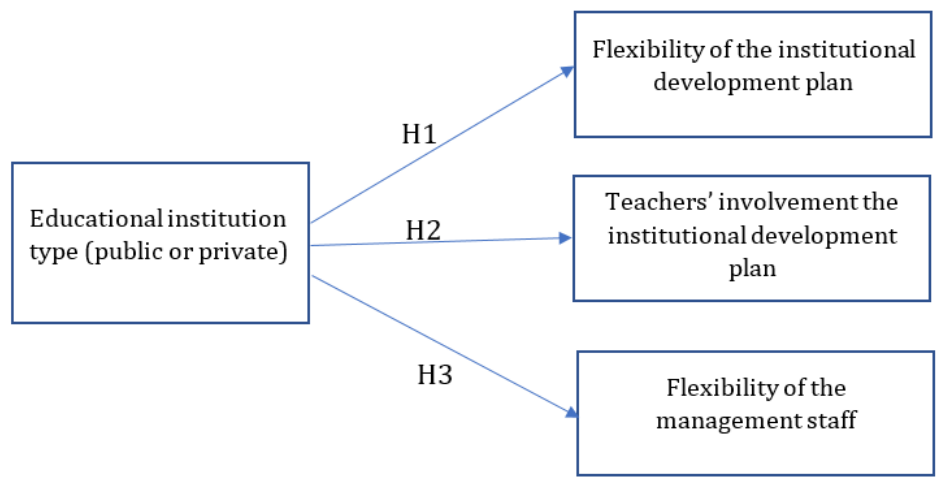

Figure 1 - Conceptual research model 
The internal consistency of the research instrument has been validated through Cronbach Alpha coefficient value $(0.762>$ minimum threshold 0.7$)$ by processing the data in the SPSS software - Table 1 .

Table 1 - Reliability Statistics

\begin{tabular}{|c|c|c|}
\hline Cronbach's Alpha & Cronbach's Alpha Based on Standardized Items & N of Items \\
\hline .762 & .788 & 20 \\
\hline
\end{tabular}

Regarding the sample adequacy, we performed Kaiser-Meyer-Olkin test, which reveals a value (.805) superior to the minimum threshold 0.8. The value of Bartlett's Test of Sphericity (Chi-Square $=583.694$, Sig $=>0.000$ ) highlights a strong relationship between the data used in the conceptual model (Table 2).

Table 2 - KMO and Bartlett's Test

\begin{tabular}{|c|c|c|}
\hline \multicolumn{2}{|c|}{ Kaiser-Meyer-Olkin Measure of Sampling Adequacy } & .805 \\
\hline \multirow{3}{*}{ Bartlett's Test of Sphericity } & Approx. Chi-Square & 583.694 \\
\cline { 2 - 3 } & $\mathrm{df}$ & 55 \\
\cline { 2 - 3 } & Sig. & .000 \\
\hline
\end{tabular}

The three hypotheses will be tested by means of Chi Square method, and coefficients of correlation Pearson R and Spearmann.

\section{Findings}

First contingency table reveals the values associated to the independent variable on rows, while the values associated to the dependent variable (flexibility of the institutional development plan) are distributed on columns. We observe significant gaps related to teachers belonging to private schools and public schools. The teachers from private school perceive the flexibility of the institutional development plans in a greater extent than their peers from public funded high schools, whose strategies are confronted with a lot of administrative burdens (Table 3). We must also emphasize the idea that both public and private high schools are evaluated on the same basis by ARACIP (Romanian agency for quality assurance on secondary education).

Table 3 - Contingency table - hypothesis 1

\begin{tabular}{|c|c|c|c|c|c|c|c|}
\hline & & \multicolumn{5}{|c|}{$\begin{array}{l}\text { The institutional development plan is flexible, adapted to the } \\
\text { realities of the socio-economic environment }\end{array}$} & \multirow{2}{*}{ Total } \\
\hline & & $\begin{array}{l}\text { Strongly } \\
\text { disagree }\end{array}$ & Disagree & $\begin{array}{c}\text { Neither } \\
\text { agree or } \\
\text { disagree }\end{array}$ & Agree & $\begin{array}{l}\text { Strongly } \\
\text { agree }\end{array}$ & \\
\hline \multirow{2}{*}{$\begin{array}{c}\text { Educational } \\
\text { institution type }\end{array}$} & public funded & 2 & 17 & 7 & 37 & 37 & 100 \\
\hline & $\begin{array}{l}\text { privately } \\
\text { funded }\end{array}$ & 0 & 0 & 1 & 27 & 72 & 100 \\
\hline \multicolumn{2}{|c|}{ Total } & 2 & 17 & 8 & 64 & 109 & 200 \\
\hline
\end{tabular}

The Chi Square test results for the first hypothesis are revealed in Table 4.

Table 4 - Chi-Square Tests - hypothesis 1

\begin{tabular}{|c|c|c|c|}
\hline & Value & df & $\begin{array}{c}\text { Asymptotic } \\
\text { Significance (2- } \\
\text { sided) }\end{array}$ \\
\hline Pearson Chi-Square & $36.301^{\mathrm{a}}$ & 4 & .000 \\
\hline Likelihood Ratio & 44.411 & 4 & .000 \\
\hline Linear-by-Linear Association & 35.403 & 1 & .000 \\
\hline \multicolumn{2}{|c|}{ N of Valid Cases } & 200 & \\
\hline a. 4 cells (40.0\%) have expected count less than 5. The minimum expected \\
count is 1.00. \\
\hline
\end{tabular}

The asymptotic significance tends to zero (lower than the significance threshold 0.05 ) and the value of the Pearson Chi Square indicator (36.301) is higher than the Pearson Chi Square table in the context of 4 degrees of freedom (9.49, according to Distribution Table available at: http://socr.ucla.edu/Applets.dir/ChiSquareTable.html ). Thus, hypothesis 1 is supported.

Both correlation coefficients have positive values: 0.422 (Pearson R) and 0.404 (Spearmann), respectively, which highlights a positive and strong correlation between variables included in hypothesis 1 (Table 5). 
Table 5 - Symmetric Measures - hypothesis 1

\begin{tabular}{|c|c|c|c|c|c|}
\hline \multicolumn{2}{|l|}{} & Value & $\begin{array}{c}\text { Asymptotic } \\
\text { Standardized } \\
\text { Errora }\end{array}$ & Approximate Tb & $\begin{array}{c}\text { Approximate } \\
\text { Significance }\end{array}$ \\
\hline Interval by Interval & Pearson's R & .422 & .046 & 6.546 & $.000^{\mathrm{c}}$ \\
\hline Ordinal by Ordinal & Spearman Correlation & .404 & .061 & 6.213 & $.000^{\mathrm{c}}$ \\
\hline \multicolumn{2}{|c|}{$\mathbf{N}$ of Valid Cases } & $\mathbf{2 0 0}$ & & & \\
\hline
\end{tabular}

a. Not assuming the null hypothesis.

b. Using the asymptotic standard error assuming the null hypothesis.

c. Based on normal approximation.

Second contingency table confronts the values associated to the same independent variable and the values associated to another dependent variable (teachers' involvement the institutional development plan). The differences in what concern the responses are not obvious such as in the first hypothesis and statistical analyses are compulsory (Table 6).

Table 6 - Contingency table - hypothesis 2

\begin{tabular}{|c|c|c|c|c|c|c|}
\hline \multirow{2}{*}{} & \multicolumn{3}{|c|}{ I am involved in the implementation of the school } \\
development plan & \multirow{2}{*}{ Total } \\
\cline { 3 - 8 } & Disagree & $\begin{array}{c}\text { Neither agree } \\
\text { or disagree }\end{array}$ & Agree & Strongly agree & \\
\hline \multirow{2}{*}{$\begin{array}{c}\text { Educational } \\
\text { institution type }\end{array}$} & public funded & 13 & 15 & 41 & 31 & 100 \\
\cline { 2 - 8 } & privately funded & 4 & 10 & 42 & 44 & 100 \\
\hline \multicolumn{2}{|c|}{ Total } & 17 & 25 & 83 & 75 & $\mathbf{2 0 0}$ \\
\hline
\end{tabular}

The Chi Square test results for the second hypothesis are revealed in Table 7.

Table 7 - Chi-Square Tests - hypothesis 2

\begin{tabular}{|c|c|c|c|}
\hline & Value & df & $\begin{array}{c}\text { Asymptotic } \\
\text { Significance (2- } \\
\text { sided) }\end{array}$ \\
\hline Pearson Chi-Square & $8.030^{\mathrm{a}}$ & 3 & .045 \\
\hline Likelihood Ratio & 8.300 & 3 & .040 \\
\hline Linear-by-Linear Association & 7.735 & 1 & .005 \\
\hline N of Valid Cases & $\mathbf{2 0 0}$ & & \\
\hline
\end{tabular}

a. 0 cells $(0.0 \%)$ have expected count less than 5 . The minimum expected count is 8.50 .

The asymptotic significance (0.045) is inferior to the significance threshold $(0.05)$ and the value of the Pearson Chi Square indicator (8.030) is higher than the Pearson Chi Square table in the context of 3 degrees of freedom (7.81), according to Distribution Table). Thus, hypothesis 2 is supported.

Correlation coefficients have positive values, but near zero: 0.197 (Pearson R) and 0.183 (Spearmann), outlining a weak correlation between variables included in hypothesis 2 (Table 8).

Table 8 - Symmetric Measures - hypothesis 2

\begin{tabular}{|c|c|c|c|c|c|}
\hline \multicolumn{2}{|l|}{} & Value & $\begin{array}{c}\text { Asymptotic } \\
\text { Standardized } \\
\text { Error }^{\mathbf{a}}\end{array}$ & Approximate Tb & $\begin{array}{c}\text { Approximate } \\
\text { Significance }\end{array}$ \\
\hline Interval by Interval & Pearson's R & .197 & .067 & 2.830 & $.005^{\mathrm{c}}$ \\
\hline Ordinal by Ordinal & Spearman Correlation & .183 & .069 & 2.616 & $.010^{\mathrm{c}}$ \\
\hline \multicolumn{2}{|l|}{$\mathbf{N}$ of Valid Cases } & $\mathbf{2 0 0}$ & & & \\
\hline
\end{tabular}

a. Not assuming the null hypothesis.

b. Using the asymptotic standard error assuming the null hypothesis.

c. Based on normal approximation.

Third contingency table reflects the values associated to the independent variable and the values associated to the third dependent variable embedded in the model (flexibility of management team with impact on performances' increase). The differences in what concern the responses are significant (Table 9), outlining a greater flexibility proved by private institutions' management teams. 
Table 9 - Contingency table - hypothesis 3

\begin{tabular}{|c|c|c|c|c|c|c|c|}
\hline & \multicolumn{5}{|c|}{$\begin{array}{l}\text { The flexibility of the management team positively influences the } \\
\text { performance of the institution }\end{array}$} & \multirow[b]{2}{*}{ Total } \\
\hline & & $\begin{array}{l}\text { Strongly } \\
\text { disagree }\end{array}$ & Disagree & $\begin{array}{c}\text { Neither } \\
\text { agree or } \\
\text { disagree }\end{array}$ & Agree & $\begin{array}{l}\text { Strongly } \\
\text { agree }\end{array}$ & \\
\hline \multirow{2}{*}{$\begin{array}{c}\text { Educational } \\
\text { institution type }\end{array}$} & public funded & 1 & 13 & 12 & 31 & 43 & 100 \\
\hline & $\begin{array}{l}\text { privately } \\
\text { funded }\end{array}$ & 0 & 1 & 3 & 20 & 76 & 100 \\
\hline \multicolumn{2}{|c|}{ Total } & 1 & 14 & 15 & 51 & 119 & 200 \\
\hline
\end{tabular}

The Chi Square test results for the third hypothesis are revealed in Table 10.

Table 10 - Chi-Square Tests - hypothesis 3

\begin{tabular}{|c|c|c|c|}
\hline & Value & df & $\begin{array}{c}\text { Asymptotic } \\
\text { Significance (2- } \\
\text { sided) }\end{array}$ \\
\hline Pearson Chi-Square & $28.210^{\mathrm{a}}$ & 4 & .000 \\
\hline Likelihood Ratio & 31.035 & 4 & .000 \\
\hline Linear-by-Linear Association & 27.485 & 1 & .000 \\
\hline N of Valid Cases & $\mathbf{2 0 0}$ & & \\
\hline
\end{tabular}

a. 2 cells $(20.0 \%)$ have expected count less than 5 . The minimum expected count is .50 .

The asymptotic significance tends to zero, as in the case of the first hypothesis, while the value of the Pearson Chi Square indicator 28.210) is higher than the Pearson Chi Square table in the context of 4 degrees of freedom (9.49). Thus, hypothesis 3 is supported.

Both correlation coefficients have positive values: 0.372 (Pearson R) and 0.367 (Spearmann), respectively, which highlights a positive correlation between variables included in hypothesis 3 (Table 11).

Table 11 - Symmetric Measures - hypothesis 3

\begin{tabular}{|c|c|c|c|c|c|}
\hline \multicolumn{2}{|l|}{} & Value & $\begin{array}{c}\text { Asymptotic } \\
\text { Standardized } \\
\text { Error }^{\mathbf{a}}\end{array}$ & Approximate Tb & $\begin{array}{c}\text { Approximate } \\
\text { Significance }\end{array}$ \\
\hline Interval by Interval & Pearson's R & .372 & .054 & 5.633 & $.000^{\mathrm{c}}$ \\
\hline Ordinal by Ordinal & Spearman Correlation & .367 & .062 & 5.558 & $.000^{\mathrm{c}}$ \\
\hline \multicolumn{2}{|l|}{$\mathbf{N}$ of Valid Cases } & $\mathbf{2 0 0}$ & & & \\
\hline
\end{tabular}

a. Not assuming the null hypothesis.

b. Using the asymptotic standard error assuming the null hypothesis.

c. Based on normal approximation.

We confirmed that all the assumptions have been validated by the statistical tests, revealing the idea that the profile of the educational institution (public or private) corelates with different managerial practices.

\section{Conclusions}

Starting from the importance of education, the specificity of the profession and the responsibility of the teacher, respectively the educational manager, in ensuring the optimal development of the personality, it follows that the teaching field should benefit from the best candidates. It is taken into account that they will work with young people, and the effects of their work will have an impact on the student's entire life.

The teacher and the educational manager who combines the forms of improvement with the individual ones of self-improvement always strives for a higher quality of his work, the one who reveals knowledge, passion for the chosen profession.

We also emphasize the idea that, in the field of education, the manager plays an important role, being responsible for the evolution of the institution he or she represents. It must mitigate the risks of overcentralization and the pressures of administrative bureaucracy, on different hierarchical levels, giving it the real possibility to formulate priorities of value and efficiency in action. In this context, the educational manager must be concerned with establishing the most effective strategies for the development of the institution.

For the success of the leadership act, the school manager must prove exigency and flexibility. The managers in the field of education must be vectors of change and carry out the training of the young generation on the basis of knowledge sharing, so that every person prepared by the school can respond to the needs of the labour market. 
The change at the level of education is already a profound algorithm for collective learning at the scale of the whole society, based on trust, honesty, competence and courage. The synthesis of this study is also based on the idea that the school managers must know the methods and techniques specific to the management. Thanks to an interdisciplinary approach, the present work can exceed the limit of argument, in order to convince the educational decision makers that a management based on the correct use of flexible methods and techniques, leads to a progress and performance in education.

Management is an attitude, a way of life, based on a real desire to work with people and to help the team succeed, and consequently the educational institution evolves. It is necessary that the person responsible for meeting the performance indicators in education should take into account the business management principles. Management is a long-term initiation process, which does not end after a training course, and continuous learning is required.

These are some of the aspects we need to consider for further research when educational managers would use a performance management system. The human resources specialists of the organization must have a good knowledge of the requirements of such a system and be able to involve and train the middle management and the employees in its design and use.

\section{References}

1. Allan, P. (2007). The benefits and impacts of a coaching and mentoring programme for teaching staff in secondary school. International Journal of Evidence Based Coaching and Mentoring.

2. Black, S. A. (2015). Qualities of effective leadership in higher education. Open Journal of Leadership, 4(02), 54.

3. Bolam, R., McMahon, A., Stoll, L., Thomas, S., Wallace, M., Greenwood, A., ... \& Smith, M. (2005). Creating and sustaining effective professional learning communities (Vol. 637). Research report.

4. Bunaiasu, C. M. (2014). Teacher's asserting premises and possibilities of efficient managerial styles. Social Sciences and Education Research Review, 1(2), 3-10.

5. Bush, T. (2008). From management to leadership: semantic or meaningful change?. Educational management administration \& leadership, 36(2), 271-288.

6. Darling-Hammond, L., Flook, L., Cook-Harvey, C., Barron, B., \& Osher, D. (2019). Implications for educational practice of the science of learning and development. Applied Developmental Science, 1-44.

7. Huffman, J. B. (2011). Professional Learning Communities in the USA: Demystyfying, Creating, and Sustaining. International Journal of Learning, 17(12).

8. Leithwood, K., \& Jantzi, D. (2008). Linking leadership to student learning: The contributions of leader efficacy. Educational administration quarterly, 44(4), 496-528.

9. McTavish, D. (2006). Further education management strategy and policy: institutional and public management dimensions. Educational Management Administration \& Leadership, 34(3), 411-428.

10. Mulford, B. (2003). School leaders: Challenging roles and impact on teacher and school effectiveness. a paper prepared for the OECD Improving School Leadership activity, available at www. oecd. org/edu/schoolleadership.

11. Ng, T. W., Butts, M. M., Vandenberg, R. J., DeJoy, D. M., \& Wilson, M. G. (2006). Effects of management communication, opportunity for learning, and work schedule flexibility on organizational commitment. Journal of Vocational Behavior, 68(3), 474-489.

12. Rosenblatt, Z. (2001). Teachers' multiple roles and skill flexibility: Effects on work attitudes. Educational Administration Quarterly, $37(5), 684-708$.

13. Tudor, L. S. (2015). The role of school activities in training/development of the professional skills specific for the teaching profession. Procedia-Social and Behavioral Sciences, 180, 984-989.

14. Walberg, H. J., Paik, S. J., Komukai, A., \& Freeman, K. (2000). Decentralization: An international perspective. Educational Horizons, 153164.

15. Wentland, D. (2003). The strategic training of employees model: Balancing organizational constraints and training content. SAM Advanced Management Journal, 68(1), 56. 